Acta Horticulturae et Regiotecturae 1

Nitra, Slovaca Universitas Agriculturae Nitriae, 2018, pp. 1-4

\title{
POSSIBILITIES OF QUANTITATIVE AND QUALITATIVE INVENTORY OF DRAINAGE DEVICES BASED ON SELECTED MAPS AND PHOTOGRAMMETRIC IMAGES
}

\author{
Karolina KRACZKOWSKA*, Piotr STACHOWSKI \\ Poznań University of Life Sciences, Poland
}

\begin{abstract}
The aim of the work was to analyse which of the selected geodetic and cartographic materials (maps and high resolution aerial images) are useful for inventory of water drainage devices. Obviously, correct determination of their quantitative and qualitative statuses can be made through field inventory. Quantitative inventory can also be done on the basis of maps. For the purpose of this research, an analysis was carried out which consisted of checking which of the selected cartographic and photogrammetric materials best reflect the location of irrigation devices in the field. The analyses were based on both digital and analogue maps at the scale of $1: 50000$ to $1: 5000$. The selected photogrammetric materials included images at the scale of $1: 10000$ and $1: 1000$.
\end{abstract}

Keywords: inventory, melioration devices, geodetic and cartographic materials, photogrammetry

According to the Water Law Act of July 20, 2017 (Journal of Laws of 2017, item 1566) water drainage systems consist in regulating water relations in order to improve agriculture soil's production capacity and to facilitate its cultivation. Water drainage devices include i.e.: ditches with functionally related structures, drainage systems (Fig.1), earthen fishponds or causeways in irrigated areas.

Most of the currently used drainage devices that were made between 1970 and 1980 are in their final phase of operation. It is 30 years for ditches and 40 years

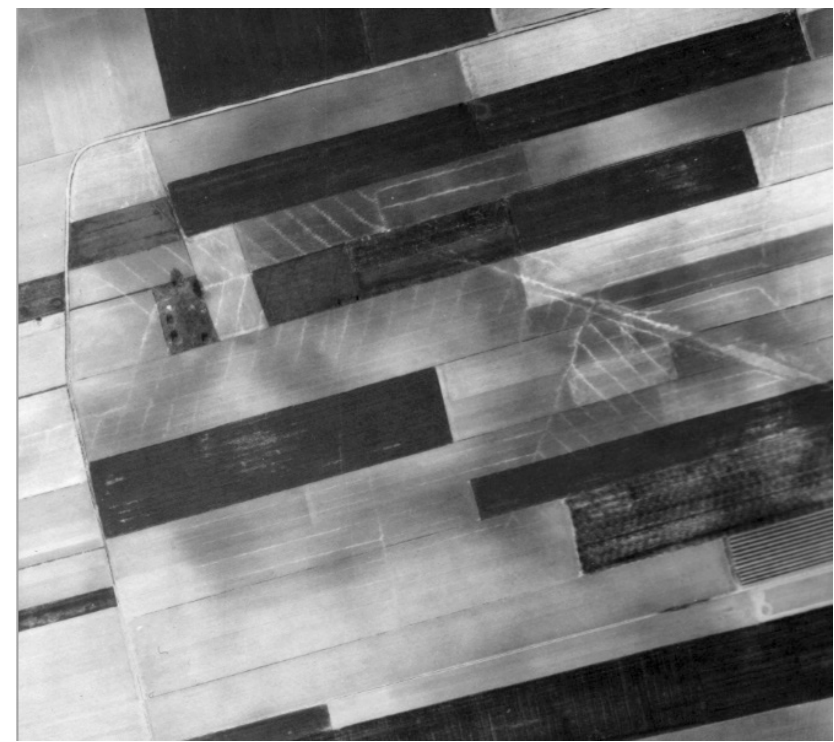

Fig. 1 Network of drains visible in the panchromatic aerial image

Source: Department of Soil Science and Land Reclamation, University of Life Sciences in Poznań for underground drainage facilities. As a consequence of many years of negligence resulting from insufficient financing, which in turn has caused shortages in ongoing maintenance, some of them do not function properly. The issue is presented in more detail in works by Kaca (2011), Ostrowski (2011), Mioduszewski et al. (2013) and Liberacki et al. (2016).

All drainage devices should be subject to periodic inventory carried out by Inspectorates and Regional Branches of the Provincial Land Drainage and Water Units Boards (in Polish: Wojewódzki Zarząd Melioracji i Urządzeń Wodnych, WZMiUW). It may proceed in different ways depending on the amount of money allocated for this purpose. The most accurate in terms of quantity and quality is field inventory. However, it is relatively expensive and time-consuming. Field inventory may also be limited due to difficulties in reaching certain places. Quantitative inventory can be carried out on the basis of maps - those that have drainage devices in their content. Unfortunately, the practice shows that maps are often outdated - they contain information that is not reflected in the field. These obstacles might be overcome with the use of photogrammetric materials. They are applied in many fields of science and economy, including taking aerial imaging for the development of flood hazard maps and flood risk maps (Kurczyński, 2012), as well as for creating Digital Terrain Models necessary for monitoring the condition of flood embankments (Long et al., 2010; Kurczyński and Bakuła, 2016). In forestry, aerial photographs allow for: specifying the species of growing trees, defining areas affected by natural disasters, monitoring pest attacks, estimating the amount of wood and facilitating work on arranging and planning forest reclamation. Based on aerial images, it is possible to create coverage maps, usage maps and maps on the decline in stands (Wężyk et 
al. 2017; R. Minařík and Langhammer, 2016). In Poland, the problems related to inventory of drainage devices on the basis of photogrammetric materials were dealt with by Świątkiewicz (1990) and Kowalczyk et al. (2016). However, from photogrammetric materials they mainly used the orthophotomap from the Geoportal and mainly focused on the usefulness of the Digital Terrain Model to identify the course of drainage ditches. The authors of the study carried out research extending them to other photogrammetric materials.

\section{Material and methods}

Performing various tests and analyses regarding drainage devices requires specific knowledge about their exact location. That is why it is so important to have the latest spatial data. Undoubtedly, the most important way to acquire them is field research, but in the era of the development of modern remote sensing techniques these have become a key source of information.

The area for which the analysis of geodesy and cartographic materials was conducted was the northern part of the Brodnica commune, located in the central Greater Poland in Poland. The study was based on geodeticcartographic materials, obtained free of charge from various companies and institutions. They were verified against their best suitability for inventory works of drainage devices. The following materials were subject to analysing: analogue and digital maps, photogrammetric materials and orthophotomaps. The study used the subsequent analogue maps: a topographic map at the scale of $1: 50$ 000, a land survey and height map at the scale of $1: 10000$ and a site location plan of drainage devices at the scale of $1: 5000$. The used digital maps were: a raster topographic map at the scale of $1: 25000$ downloaded in digital form from the WMS server located on Geoportal, web portal to find and access geographic information (http://www.geoportal.gov.pl, date of access: 04.20.2017) using a free application Geox Editor 2.0 Demo, the Map of the Hydrographic Division of Poland 2010 at the scale of $1: 50000$ and the List of Damming Structures at the scale of $1: 50000$. The last two were available on the Geoportal of the National Water Management Board (http:// geoportal.kzgw.gov.pl/imap/, date of access: 22.05.2017). In addition to the abovementioned maps, photogrammetric materials were used in the work. These included 106 panchromatic aerial images, taken on 29.04.1988, at the scale of $1: 10000$, belonging to the Department of Soil Science and Land Reclamation, University of Life Sciences in Poznań. The study also included orthophotomaps from Geoportal and Google Maps. These materials were supplemented by technical documentation of the Commune Water Company in Brodnica, which consisted of a technical description and a list of technical data from 1986 obtained from resources held by the Inspectorate of Greater Poland Provincial Land Drainage and Water Units Board in Śrem. Additionally, the authors used aerial photographs at the scale of $1: 1000$ and photos were taken with the use of a drone.

The purpose of the research was to answer the question: which of the selected cartographic and photogrammetric materials best reflect the location of irrigation devices in the field. The testing primarily consisted in visual analysing. Both maps and photos were corrected to improve their readability. The data on drainage devices included in individual geodetic-cartographic materials were compared in the computer program QGIS 2.18.0. The basis for performing comparisons between materials was the orthophoto at the scale of $1: 10000$ (set in the coordinate system PUWG 1992 EPSG: 2180 ), as a type of graphic layers that most objectively reflect the real situation. Subsequently, by means of georeferencing, the following materials were read into it: the topographic map at the scale of $1: 25000$, the site location plan of drainage devices at the scale of $1: 5000$ and the panchromatic aerial images at the scale of $1: 10000$.

\section{Results and discussion}

The visual analysis of source materials in terms of their suitability for inventory of drainage devices proved that the topographic map at the scale of $1: 50000$ was not suitable for this purpose. This was due to its scale, which caused a significant generalisation of situational details. The land survey and height map at the scale of $1: 10000$ enabled general ground recognition and making a photo-sketch from analogue photos at the scale of $1: 10$ 000. Unfortunately, these maps are inconvenient due to their large format. The most useful map was the site location plan of drainage devices at the scale of $1: 5000$ (Fig.2), since it contained all information about field elements of the drainage system. Such maps also contain information on the boundaries of municipalities and communes, water companies, as well as individual villages and competitive areas, for which specific irrigation equipment exerts a beneficial influence. In addition, green areas, lakes, existing ditches, concrete pipelines and point facilities such as drainage outlets, culverts, gates and wells were marked along with their short characteristics (name and diameter). Their only drawback is their manual updating, therefore, the position of the elements is approximate. It should be borne in mind that elements removed from the records are deleted in an analogue way; as a consequence, the readability of these maps is significantly reduced as corrections are applied.

Similarly, the Map of the Hydrographic Division of Poland 2010 at the scale of $1: 50000$ was not suitable for carrying out inventory of drainage devices due to its small scale. Its considerable disadvantage was that the database on which the basis of the map was displayed was not complete. The list of damming structures at the scale of $1: 50000$ was also characterised by a small scale, whereby the location of damming objects was only approximate.

The Raster Topographic Map allowed for selection of the displayed scale, but there were very few details about drainage systems. The orthophoto from Geoportal was made of aerial photographs from the Central Geodetic and Cartographic Documentation Centre resources that were taken with high-resolution quality. The map allowed for noticing water reservoirs, channels, ditches, culverts, gullies, wells and earthen fishponds. Additionally, it was possible to display it on the selected scale. The second analysed orthophotomap, from Google Maps, also had the option of selecting the scale of display, however, it featured lower 
Table 1 Drainage devices found in the analysed materials

\begin{tabular}{|c|c|c|c|c|c|c|c|c|c|c|}
\hline & 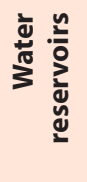 & 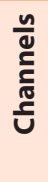 & $\begin{array}{l}y \\
\frac{y}{u} \\
\stackrel{t}{0}\end{array}$ & $\frac{\frac{n}{d}}{\frac{\Delta}{5}}$ & $\frac{\stackrel{n}{\frac{n}{u}}}{\frac{3}{3}}$ & $\frac{y}{\frac{y}{D}}$ & $\stackrel{n}{\bar{c}}$ & 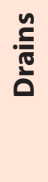 & 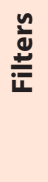 & 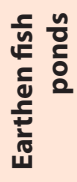 \\
\hline $\begin{array}{l}\text { Topographic map } \\
\text { at the scale of } 1: 50000\end{array}$ & + & + & - & - & - & - & - & - & - & + \\
\hline $\begin{array}{l}\text { Land survey and height map } \\
\text { at the scale of } 1: 10000\end{array}$ & + & + & + & - & + & - & - & - & - & + \\
\hline $\begin{array}{l}\text { Site location plan of drainage devices } \\
\text { at the scale of } 1: 5000 \mathrm{~m}\end{array}$ & + & + & + & + & + & + & + & + & + & + \\
\hline $\begin{array}{l}\text { Map of the Hydrographic Division of } \\
\text { Poland of } 2010 \text { at the scale of } 1: 50000\end{array}$ & + & + & $+/-$ & - & - & - & - & - & - & + \\
\hline $\begin{array}{l}\text { List of Damming Structures } \\
\text { at the scale of } 1: 50000\end{array}$ & + & + & $+/-$ & - & - & - & - & - & - & + \\
\hline $\begin{array}{l}\text { Raster topographic map } \\
\text { at the scale of } 1: 25000\end{array}$ & + & + & + & - & - & - & - & - & - & - \\
\hline Aerial imagery at the scale $1: 10000$ & + & + & + & - & - & - & - & + & + & + \\
\hline Orthophoto from Geoportal & + & + & + & - & + & + & + & - & - & + \\
\hline Orthophoto from Google Maps & + & + & + & - & - & - & - & - & - & + \\
\hline
\end{tabular}

+- included, ,- - excluded, +/- - partially included

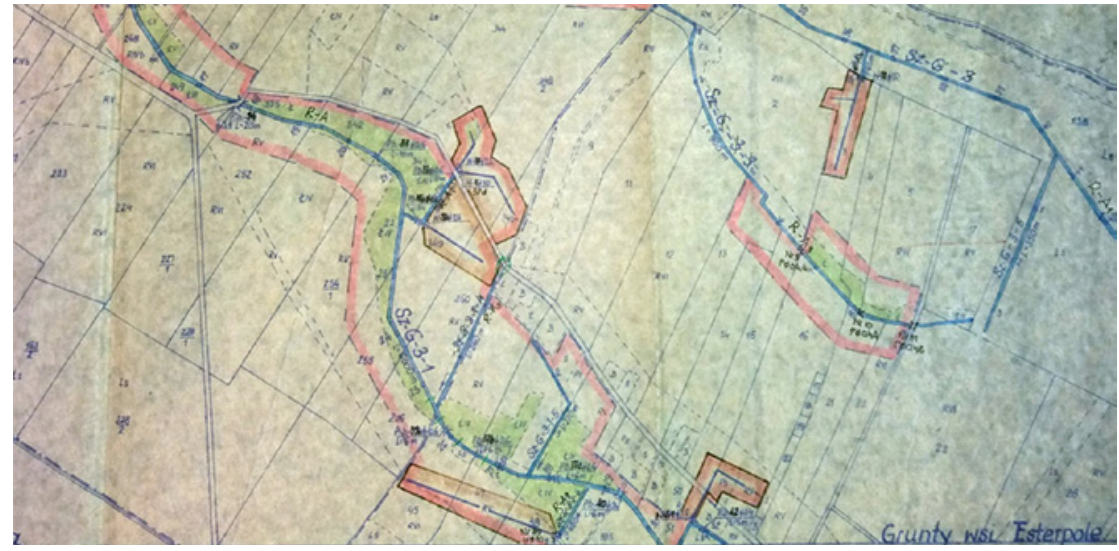

Fig. 2 Fragment of the site location plan of drainage devices Source: Inspectorate of Greater Poland Provincial Land Drainage and Water Units Board (WZMiUW) in Śrem resolution than the orthophotomap from Geoportal. It is not known when the photographs, based on which it was created, were taken. Panchromatic aerial photographs at the scale of $1: 10000$ allowed for making a quantitative inventory of line objects, and depending on the readability of photos, sometimes also point objects. Aerial photographs at the scale of $1: 1000$ showed drainage devices in the greatest detail. Yet, the disadvantage of both these types of images is that they are expensive to obtain. The photos can also be taken with the help of drones (Fig.3).
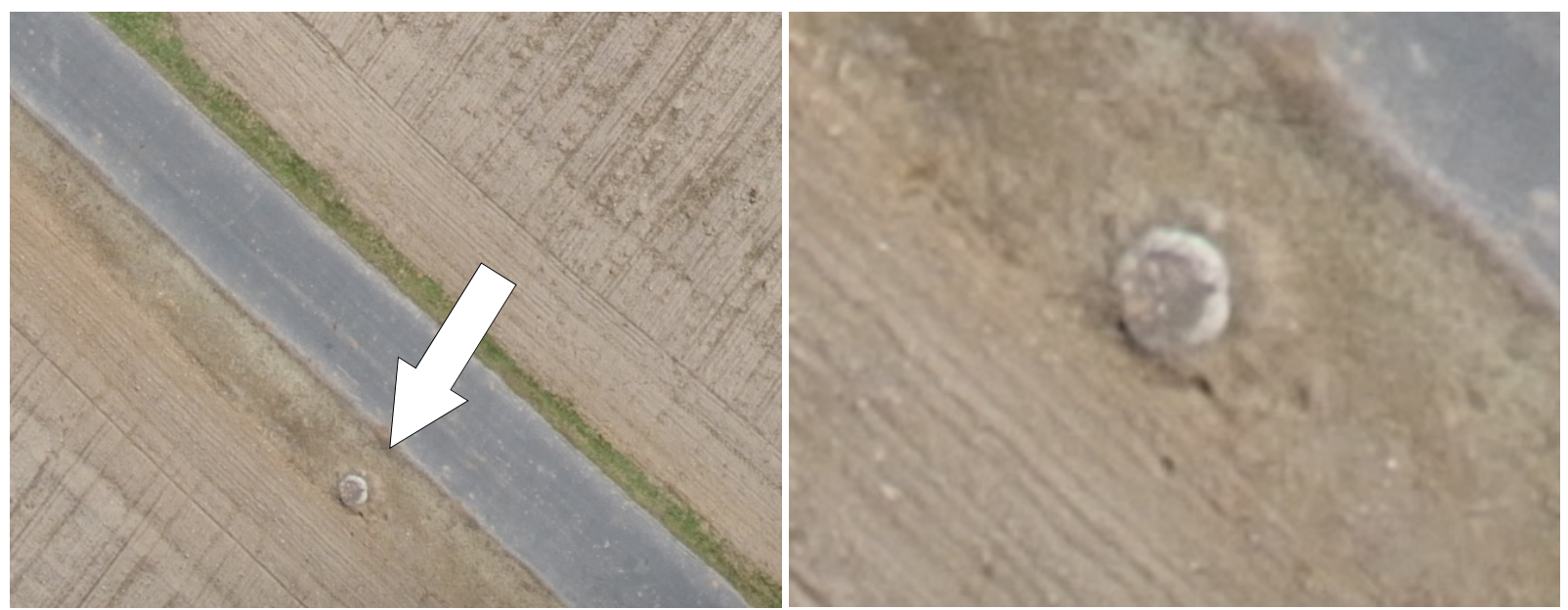

Fig. 3 The photograph of a drainage well taken using the eBee Plus drone Source:TPI sp. zo. o. 
GeoMelio Portals are Internet portals containing the same information as the land maps of land drainage devices; only the representation of objects is in the digital form. Their digital form makes them more convenient than analogue maps. The only downside is that there is no single base for the entire country, and only half of the Provincial Land Drainage and Water Units Boards provide such information on their websites.

The topographic map at the scale of $1: 25000$ includes the network of open ditches. However, due to its generalisation, it represented on average one ditch every-second spacing.

Subsequently, there were compared the panchromatic aerial photographs at the scale of $1: 10000$ with the situational map of drainage devices at the scale of $1: 5$ 000. The photographs at the scale of $1: 10000$ effortlessly allowed for determination of places with ditches, regardless of their shape - either in the form of a broken line or a curve. Linear elements were often visible due to the neighbouring growing vegetation. It was possible to deduce the existence of culverts under some roads from wide channels and roads running over them. After enlarging the photographs to the scale of $1: 1250$, there were also seen culverts in the fields.

\section{Conclusion}

The analysis proved that panchromatic images in the visible band taken at the scale of $1: 10000$ or $1: 1000$ can be used to perform inventory of linear, ground-based elements of the drainage system, i.e. channels and ditches. When the scale is enlarged, it is also possible to see the location of culverts. Undoubtedly, the right season and proper weather conditions, during which photogrammetry takes place, have a big impact on the photographic quality of drainage devices. To a large extent, the readability of photogrammetric images depends on land cover vegetation, which simultaneously can either facilitate (as an indirect interpretive feature) or make it difficult (obstructing the view) to interpret the picture. In order to show an underground drainage network in photos, photographic documentation should be made short after the precipitation has stopped and using multispectral cameras.

Analogue (available at WZMiUW) or digital (made available on websites by some WZMiUW) situational maps of drainage devices are useful for making inventory of drainage devices, as they contain all drainage devices located in a given area. They should provide the latest available data on the drainage system, therefore, it is regrettable that often they are not updated on a regular basis

When choosing an orthophotomap for inventory purposes, attention should be paid to its high resolution and the maximum scale for display. Both of these parameters will ensure effective recognition of objects located in the field. Geoportal provides a high quality orthophotomap. For a more efficient computer processing of materials, it is worth to download a fragment of an orthophotomap with the analysed area and upload it as one of the raster layers. This will save time the program uses to update the WMS layer every time the view on the computer screen changes. In addition, it is worth checking if the orthophotomap downloaded via the WMS and from the Geoportal website is the same, because, as demonstrated in the study, it does not have to be and they may differ from each other. Ground Sampling Distance and the date of taking orthophotomaps prepared on Geoportal can be verified in indexes available at the CODGiK website (http://www.codgik.gov.pl/index. php/skorowidze.html).

Inventory of drainage devices can be done without financial outlays in an easy way by using free of expense and open for general use orthophotomaps along with free GIS software. Undoubtedly, the result of analysing (the quantity and quality of information obtained) is influenced by the experience and extensive qualifications of the person interpreting images.

\section{References}

CODGiK. 2017. http://www.codgik.gov.pl/index.php/skorowidze. html (access date: 16.06.2017)

GEOPORTAL. 2017. http://www.geoportal.gov.pl (access date: 20.04.2017).

KACA, E. 2011. Melioracje wodne jako czynnik ograniczający skutki ekstremalnych zjawisk hydrometeorologicznych. In Wiadomości Melioracyjne i Łąkarskie, 2011, no. 3, pp. 111-114.

KOWALCZYK, T. - POKŁADEK, R. - GOŁUCH, P. - ORZEPOWSKI, W. KOWALSKA, J. 2016. Dane przestrzenne jako narzędzie identyfikacji i inwentaryzacji urządzeń wodnomelioracyjnych - studium przypadków. In Wiadomości Melioracyjne i Łąkarskie, 2016, no. 3, pp. 123-128.

KURCZYŃSKI, Z. 2012. Mapy zagrożenia powodziowego i ryzyka powodziowego a dyrektywa powodziowa. In Archiwum Fotogrametrii, Kartografii i Teledetekcji, 2012, no. 23, pp. 209-217.

KURCZYŃSKI, Z. - BAKUŁA, K. 2016. SAFEDAM - zaawansowane technologie wspomagające przeciwdziałanie zagrożeniom związanym z powodziami. In Archiwum Fotogrametrii, Kartografii i Teledetekcji, 2016, no. 28, pp. 39-52.

LIBERACKI, D. - BYKOWSKI, J. - KOZACZYK, P. - SKWIERAWSKI, M. 2016. Ocena konserwacji i modernizacji urządzeń melioracji podstawowych na obszarze północnej Wielkopolski. In Inżynieria Ekologiczna, 2016, no. 49, pp. 66-73.

LONG, G. - MAWDESLEY, M.J. - SMITH, M. - TAHA, A. 2010. Simulation of airborne LiDAR for the assessment of its role in infrastructure asset monitoring. Proceedings of the International Conference on Computing in Civil and Building Enginerering, Tizani W (ed). Nottingham, UK : Nottingham University Press, 2010.

MIODUSZEWSKI, W. - LIPIŃSKI, J. - KOWALEWSKI, Z. 2013. Melioracje - gospodarka wodna na potrzeby rolnictwa. In Wiadomości Melioracyjne i Łąkarskie, 2013, no. 2, pp. 52-59.

MINAŘíK, R. - LANGHAMMER, J. 2016. Use of a multispectral UAV photogrammetry for detection and tracking of forest disturbance dynamics. In The International Archives of the Photogrammetry, Remote Sensing and Spatial Information Sciences, vol. XLI-B8, XXIII ISPRS Congress, 2016.

OSTROWSKI, K. 2011. Rola urządzeń melioracji szczegółowych w rolnictwie i środowisku przyrodniczym. In Wiadomości Melioracyjne i Łąkarskie, 2011, no. 4, pp. 155-160.

ŚWIĄTKIEWICZ, A. 1990. Przydatność zdjęć lotniczych w inwentaryzacji sieci drenarskich. In Zeszyty Naukowe Akademii Rolniczej im. H. Kołłątaja w Krakowie, 249, Sesja Naukowa, 28, cz. II, pp. 157-183.

WATER Law Act of July 20. 2017. In Journal of Laws of 2017, item 1566. WĘŻYK, P. - MUCHA, M. - SZOSTAK, M. 2017. Mapa użytkowania i pokrycia fragmentu Gorczańskiego Parku Narodowego opracowana w oparciu o fotointerpretację cyfrowych ortofotomapy lotniczych CIR z 2011 roku. In Roczniki Geomatyki, vol. 15, 2017, no. 1(76), pp. 119-131. 